Vadim Postolachi ${ }^{1}$, Renata Stasiak-Betlejewska ${ }^{2}$

\title{
IMPROVEMENT OF THE TRANSPORTATION \\ BY USING KEY NATIONAL PROJECTS \\ - COMPARISON STUDY OF ROMANIA AND MOLDOVA
}

\begin{abstract}
Transportation is one of the key elements of country competitiveness increase in the context of the national economy growth. The main goal of the paper is to present key national projects on the transportation in chosen European countries. The review of data on the transportation in Romania and Moldova have been presented and analyzed in the paper. The main elements of the national projects on the national roads have been identified in the aim of the transportation improvement. Statistical data presented in the paper concerns research period $2004-2014$.
\end{abstract}

Key words: transportation, national project, improvement

\section{Introduction}

The idea of transport has been taken with the advent of human life. It is gradually developing concept from human physical limits to road, rail, sea, air and via pipelines. Transportation is moving from location to location of persons, goods, energy or information. It is the economic branch without who's the other sphere of national economy could not expand. Transport cannot be reached in the absence of goods or passengers, as they are a result of the economic activity. Transport includes following branches: transport infrastructure, vehicles, and transport management.

\footnotetext{
${ }^{1}$ BSc, University of Petrosani, Romania, e-mail: vadimpostolachifiodor@mail.com

${ }^{2}$ Ing. PhD., supervisor, Institute of Production Engineering, Faculty of Management, Czestochowa University of Technology, e-mail: renatastasiak@wp.pl
} 


\section{The organization of the transportation in Romania and Moldova}

Romania has an area of $238,391 \mathrm{~km}^{2}$ and it is the seventh most populous member state of the European Union. The capital of Romania is Bucharest. Transport infrastructure in Romania is owned by the state and administered by the Ministry of Transport, Constructions and Tourism. There are all kinds of contemporary transport means in Romania such as: the railway transport, the road transport, the air transport, the sea transport.

The railway transport is one of the most used means of transport. National railway transport infrastructure of Rumania is managed by the national CFR (Romanian Railways). Bucharest is the only city in Romania which has a metro that was inaugurated in 1979. Today it is the most used mean of the public transport in Bucharest with an average of 600,000 passengers per day. Road transport offers the greatest efficiency and enables short loading cargo directly from point of dispatch and downloading them directly to your destination without the need for transhipment and additional manipulations. Romania has $697.76 \mathrm{~km}$ of the highway since July 2015. The air transport is the fastest mean of the transport. In Romania there are 62 airports with paved runways 25 with unpaved runways 37 and a Heliport. In 1954, there was established TAROM (Romanian Air Transport), which operates until today. Romanian airline Blue Air is the first $100 \%$ privately owned and was founded in 2004. Blue Air fleet currently consists of 9 modern Boeing and 737 aircraft. Romanian river transport is still at a very low level but with great growth potential due to navigable rivers and the Danube River. Romanian waterways are used more for export or import of goods than goods transport within the country. In the first quarter of 2010, external traffic (2.376 million tons capacity) exceeded domestic traffic (2.207 million tons capacity). Romania to the Black Sea area with three seaports Constanta, Midia and Mangalia. Constanta Port is the largest port in 
Romania, while also is the largest port of the Black Sea and fifth seaport of Europe.

The capital city of Moldova, officially the Republic of Moldova, is Chişinău. It has an area of $33,846 \mathrm{~km}^{2}$ with 2,9 million inhabitants. In Moldova, the auto transport is predominant both in freight transport and in the passenger, it is the main mean of transportation of the goods in trade relations between Moldova and other countries, but also in internal activities (table 12.1). With a maximum accessibility, this type of transport is used by most industries. Moldovan Railways (CFM) is the national railway company of Moldova. CFM manages with the infrastructure, the passenger and the freight rail in Moldova. CFM is the successor of MJD that is a subdivision of Railways of the Soviet Union. Number of employees, Moldovan Railroads is the largest enterprise in Moldova. The total length of the railway network is administered by CFM $1232 \mathrm{~km}$ of which $1218 \mathrm{~km}$ is broad gauge $(1,520 \mathrm{~mm})$ and $14 \mathrm{~km}$ standard gauge $(1435 \mathrm{~mm})$. Moldovan railway travelled at speeds of up to $90-100 \mathrm{~km} / \mathrm{h}$, the speed is more portions of $60-70 \mathrm{~km} / \mathrm{h}$. The network of the public road in Moldova is $12719 \mathrm{~km}$ with $87 \%$ of the paved surface. There are $3669 \mathrm{~km}$ of national roads and 6834 kilometres of local roads. However, its quality does not meet international standards. Public roads are the main way of inland transport, and most are in generally unwell condition. In addition the lack of fuel and prices hampers transport interurban car. About 20\% of the public roads of Moldova are in critical technical condition, missing road markings and road signs are missing or not properly maintained. In Moldova, the Dniester and Prut rivers are navigable, but shipping plays a too little important role in the transport system. In the absence of preferential agreements with Romania Galati port for use or for use ports Reni Ukraine or Odessa, Moldova has invested huge sums in Giurgiulesti International Free Port, Danube, where in 2006 was finished construction of an oil terminal. The air transport is one of the most preferred ways for foreign tourists visiting the country. The airlines of Moldova, together with foreign companies, passenger transportation services by scheduled, provide direct links to 
about 20 destinations. The country's main airport is the Chisinau International Airport. The air of Moldova airline with 5 aircraft is the national carrier of the Republic of Moldova. The air Moldova is a member of IATA and ICAO. The growth and the productivity in a given region is closely linked to the transportation infrastructure, as transport systems generate higher productivity through lower logistic costs, streamline inventory and easier access to markets and labour supply. In short, accessibility and connectivity are key factors for increasing economic competitiveness. A mobility represents, in turn, a key result of investments because ensure shipments multiplying factors with a positive effect on economic growth and productivity. Table 1 presents the volume of the transported cargo and goods carried over by transport enterprises by different transport means in Moldova in 2015. It confirms, that majority of goods are carried over by auto means of transport (7640, 7 thousand tons).

Table 1. The volume of transported cargo and goods carried over by transport enterprises by transport means in Moldova in 2015

\begin{tabular}{|l|r|}
\hline Goods carried (thousands tons) & $\mathbf{1 1 9 6 3 , 1}$ \\
\hline Total: & 4169,8 \\
\hline Railway & 7640,7 \\
\hline Auto & 152,0 \\
\hline River & 0.6 \\
\hline Air & $\mathbf{3 7 3 8 , 8}$ \\
\hline During goods (million tons - km) & 962,6 \\
\hline Total: & 2775,0 \\
\hline Railway & 0,4 \\
\hline Auto & 0,8 \\
\hline River & \\
\hline Air &
\end{tabular}

Source: National Bureau of Statistics of the Republic of Moldova. 
Number of passengers in correlation to the public transport modes has been presented in Table 2. Data presented in the table confirms that busses and minibuses are used by the majority of passengers $(98827,9)$.

Table 2. Number of passengers and over 2015 passengers on public transport modes

\begin{tabular}{|l|r|}
\hline Public transport: & \\
\hline railway & 3044,5 \\
\hline buses and minibuses & 98827,9 \\
\hline river & 139,4 \\
\hline aerial & 1085,4 \\
\hline
\end{tabular}

Source: National Bureau of Statistics of the Republic of Moldova.

\section{Key investments in Romanian transportation}

Analysis of key investments in transportation in Romania was done in accordance to data collected with applying data of Statistics National Bank of Romania and the Department of Enterprise Structural Statistics and the Statistical Business Register Department of the National Institute of Statistics (Fig. 1).

One of the analyzed project on the investments in transportation in Romania is a project titled Adaptability to increase the competitiveness of road transport in Romania that is co-financed by the European Social Fund through the Sectoral Operational Program Human Resources Development 2007 -2013 and launched by the National Union of Road Carriers from Romania (UNTRR) and the Foundation "Centre for Entrepreneurship and Executive Development (CEED Romania). The project started on June 1st, 2010 and project was planned to last 24 months, addressing the workers and companies in the road transport sector in six developing regions of Romania: West, Northwest, Northeast, Central, Southern and Bucharest - Ilfov. Its overall objective was to 
increase the adaptability and competitiveness by improving human and organizational capacity in the road transport sector, actively promoting at the same time, equal opportunities principles, improving existing mentalities and developing new attitudes in accordance with standards and best practices.

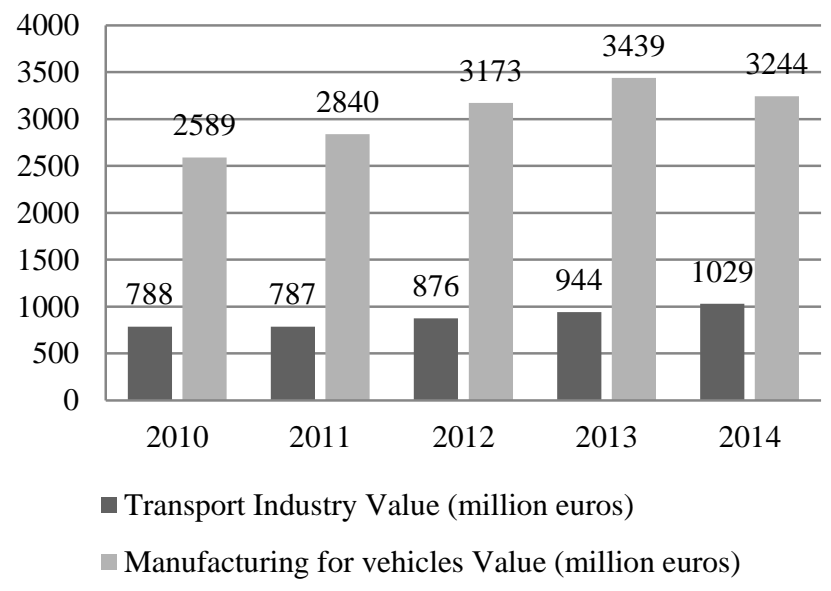

Fig. 1. Distribution of foreign direct investments in Romania economic activities 2010-2014.

Source: The National Bank of Romania.

Romania had only one bridge on the Danube until 2013. Bulgaria and Romania opened of the second bridge "Calafat - Vidin" on $14^{\text {th }}$ June in 2013 that is a railway bridge and road connecting Calafat (Romania) and Vidin (Bulgaria ). The mentioned bridge is a part of Pan-European Transport Corridor. The contract for the bridge built by the company Fomento de Construcciones y Contratas amounts to 99,955,946 Euros. The total cost of the work is set at 236 million Euros. Construction of the infrastructure facility as important as the Vidin - Calafat Bridge has spurred authorities on both sides. Bulgaria and Romania have suggested realization in the near future similar bridges linking two countries in areas 
of the economic interest or transit increased. For the next years major investment in the transport infrastructure through modernization concerns national and local interest roads and the construction of highways.

The investment is also aimed at upgrading of the railways and the increase of the average speed that is currently at a low level compared to other European countries, but also the construction of new railways, such as "Vâlcele-Ramnicu Valcea" located on Corridor IV European transport. Other measures to be taken to Romanian infrastructure modernization is the construction of new airports (Ghimbav - Brasov, Galati-Braila etc.) and capacity expansions of existing ones. Marine transport is intended to increase traffic on the Danube.

The European Commission adopted the Operational Program for Infrastructure of Romania Mare (POIM) for the period 2014-2020. POIM is a major investment package of almost 9.5 billion Euros of EU regional funds, money that will be invested in environmental projects, energy and transport. This investment package, the largest operational program of Romania and the second in Europe in size helps to develop a sustainable and environmentally friendly transport system. The program strengthens the economic competitiveness of Romania and cities and regions what bring Romania closer to the European Union. Rail and road connections better also create new business opportunities, reduce costs and time spent travelling carriage of goods by us all. According to the Ministry of European Funds/MFE/via POIM 2014-2020 shall ensure funding for key development priorities of Romania in: the transport sector, in line with the Master Plan of Transportation, with an allocation of $€ 6.8$ billion (of the EU contribution is $€ 5.1$ billion). The program implements the Master Plan transport strategy for the coming years the Romanian transport sector. Since transportation is a key area for growth and competitiveness in the economic development, Master Plan assess specific needs, identifies the bottlenecks and missing links and establishes clear and achievable objectives for future projects. Master Plan is aimed at improvement of the existing infrastructure to develop a sustainable urban 
transport and environmentally friendly and to complete the TEN-T core network in Romania.

Antares Group, which opened last year in 2015 the first power station with compressed natural gas vehicles (GNCV), will invest 7 million Euros until 2019 in expanding its nationwide network. Antares Group expects interest in this type of fuel to grow in the future, GNCV is intended diesel engines can be converted into diesel dual-GNCV. The cost of the fuel, liquefied petroleum gas version for gasoline is on average $50 \%$ lower than that of traditional fuels. According to information available, the price of kilo of GNCV in Romania is 0.74 Euro. The highest price is recorded in Sweden (1.74 Euros per kilogram). The opposite is in Moldova (0.4 Euros). The price of a litter of diesel is around 1 Euro due to lower international price of a barrel of heavy oil.

CE approved new policy on EU transport infrastructure in 20142020, following two of the nine major European corridors crossing Romania, where they can receive funding several projects, such as rail Arad Brasov Bucharest and Constanta port Constant. EU's multiannual budget for 2014-2020 allocates 26 billion for the nine transport corridors. Romania is included in transport corridors East/Eastern Mediterranean and the Rhine-Danube, show documents published by the European Commission. Thus, Orient/East Mediterranean is to connect maritime transport infrastructure from the North Sea, the Baltic, Black Sea and Mediterranean ports optimizing the use of EU countries. In the RhineDanube corridor, Romania can access EU funds for several projects of railway infrastructure and waterways. Romania is included in the corridor Rhine-Danube and several projects for ports and transport Fluvial funds 26 billion allocated to transport under the "Connecting Europe Facility" will serve in practice as 'seed capital' to stimulate additional investment from the Member States to complete the connections and cross-border links difficult that otherwise would probably not be built, it said in a statement the CE. The cost of implementing the first phase of funding the core network for the period 2014-2020 is estimated at 250 billion Euros. The core network is to be completed by 2030 . 


\section{Key investments of Moldovan transportation}

Reform of the electric transport in Chisinau, its renovation began in 2010, according to "Public Transport Project", a project submitted by the European Bank for Reconstruction and Development (EBRD) and European Investment Bank support and European Neighbourhood Investment Fund of the European Commission estimates the total cost of the project is 13.0 million Euros, as follows: EBRD (5.0 mln Euro); EIB (5.0 mln Euro); EU IVF (3.0 mln Euro grants). Thus, with the support of the Chisinau City Hall on October 6, 2011102 buses were delivered AKSM-321 model and equipment maintenance trolley ( 3 units of the car wash, three complete tire changing equipment and line diagnostics).

Giurgiulesti is the only port accessible to ships Moldova, situated on the banks of the Danube in the south, sandwiched between Romania and Ukraine. The owner, who is the operator and an investor, General of Giurgiulesti International Free Port is managed by a Dutch company "Danube Logistics" SRL. The port was commissioned on 26 October 2006, after 10 years of construction. Danube Logistics has entered into an agreement with the Government which rents this place for a period of 99 years. In exchange for this investment, the Government was committed to develop infrastructure to Giurgiuleşti. It is a substantial project. It is a private operator, but the port will be available for everyone, for all customers who will be willing to bring cargo in port. They are welcome. Giurgiulesti port consists of a petroleum terminal, freight and passenger port and an industrial zone. The oil terminal was built in foreign investment worth 35 million USD. Passenger Port (investment of 10 million USD) has a capacity of 300 passengers per day. The grain terminal (investment of 12 million USD) used to transport grain by sea to and from Moldova, if necessary. The only seaport in the South increases its territory. To stimulate the development of trade naval surface, Giurgiulesti will be extended over 60 hectares. According to the Government project in 2015, the authorities intend to build new stores in 
the region mooring of vessels and barges to meet growing demands from local and international companies.

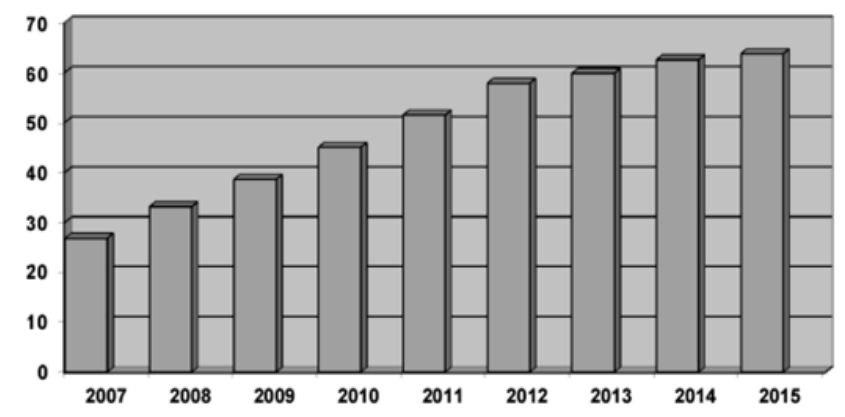

Fig. 2. Cumulative investment volume in International Free Port "Giurgiulesti" (per year in mln USD).

Source: The Moldovan Government, the Ministry of Economy based on: http://www.mec.gov.md/ro/content/portul-international-liber-giurgiulesti

In 2014, there was launched an investment project aimed at modernization of the rail network in Moldova worth 100 million Euros that will be implemented until 2020. The project was granted by the European Bank for Reconstruction and Development and European Investment Bank. Initiating negotiations on the Loan Agreement between the Government, EBRD and EIB, as well as the composition of the negotiators, they were approved today by the Cabinet of Ministers. In the opinion of the Minister of Transport and Road Infrastructure Vasile Botnari, the project comes to support the actions of modernization and development of the rail network in the situation when both infrastructure, communications and the rolling stock Enterprise "Moldovan Railroads" requires major investments. In the opinion of the mentioned Minister, these important investments, whose 95 million Euros are in the form of loan and 5 million Euros grant, are expected to be targeted for overhaul of railway lines, the acquisition of wagons and locomotives us. The group of negotiators is led by the Deputy Minister of Transport and Road 
Infrastructure and a part composition of professionals in the legal, economic, financial and commercial.

Under the contract on October 21, 2015, restoring stretch of railway will create a comfort to transport goods. The railways of Ukraine and Moldova have agreed to carry out a project to restore a portion of the railway sector Berezino - Basarabeasca, bypassing Transnistria, "This is a direct way from Moldova to the ports of Odessa. In the negotiations, it has reached an agreement on restoring circulation and overhauls the infrastructure sector. The conditions required for the project are organizing the movement of at least six pairs of trains within 24 hours in accordance with the current legislation of Ukraine and Moldova, but also the inclusion of the project in the financing plan of the railways for 2016. Project promoters are invited also to search the investors.

The Chisinau International Airport had the inauguration ceremony of the works on extension and reconstruction of Chisinau Airport terminal in 2014, what influence on the increase of the passengers number (Fig. 3). Avia Invest is implementing the strategic development plan of the airport, taking all the necessary measures to ensure the functionality of the airport in a reasonably efficient manner. There was started the working process on the extension and the reconstruction of the terminal in the East, West and South $\left(9605 \mathrm{~m}^{2}\right)$. The project involves the construction of a new zone with an area of $4155 \mathrm{~m}^{2}$ and rebuilding and retooling the existing areas $\left(5450 \mathrm{~m}^{2}\right)$ in accordance with international requirements and standards. Thus, the terminal extension and reconstruction (extension of the Arrival Zone, the departure Zone, the common hall Zone, the luggage Zone) will significantly reduce the inconveniences for the passengers by creating a pleasant atmosphere before the flight and increasing service capacity to 750 passengers per hour in each direction (now 420 passengers/hour). 


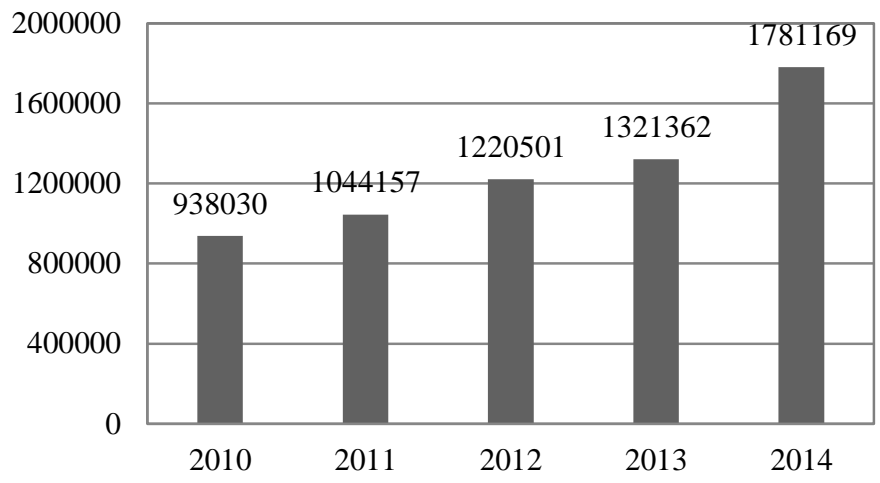

Fig. 3. The annual number of passengers who used the Chisinau international airport in recent years.

Source: Chisinau airport Avia Invest based on: http://www.airport.md/passenger-en/

The official presentation of the "Chisinau International Airport" model was held in December in 2015. The event took place at the airport in the capital. The layout was located in the departure hall of Terminal. It gives the opportunity to all passengers to see how the airport will look like in 2030 after its reconstruction. The organizers presented the comprehensive development strategy of the Chisinau Airport including consecutive stages of the investments made by LLC "Avia Invest". Model illustrates both the current infrastructure and its development prospects in the next 20 years, rebuilding the entire airport could be completed by 2030. The first phase will start in 2014, the second phase in 2022 and the third phase from 2025 2030. construction of new terminal will start from 2025.

In 2015, the Ministry of Transport and Road Infrastructure in Moldova launched the railway station Chisinau-Iasi (Station Socola) - a design that has been talking for years and has been achieved by the new team of the Ministry, in less than one month. Iasi-Chisinau train travel is more than a simple investment in rail transport, as this project has direct 
implications not only in tourism but also in education, culture and the process of European integration.

\section{Conclusions}

Romanian transport infrastructure is characterised by the poor quality. Despite some recent reforms, Romania still lacks a robust framework for developing, vetting, prioritizing, and executing public investment projects. The central government project pipeline is clogged with old projects. There are over 500 central-government investment projects with a value equivalent to $31 \%$ of GDP. Many projects have long implementation periods with 78 projects expected to take more than 10 years to complete, including one with a duration of 42 years. For the 2007-13 programming period, Romania has absorbed about 52\% of the EUR 19.1 billion (15\% of 2007 GDP) of SCF at its disposal. It is eligible for another EUR 22.5 billion (14\% of GDP) in SCF during 2014-20. Romania's low absorption rate reflects weak project management capacity in the government and in beneficiaries and a preference for initiating projects funded through the state budziet (RALYEA J., StePanyan V., Xu T.T., RaZAFimahefa I.F., LiU L.Q., BABICI, G. 2015).

The Republic of Moldova is provided with sufficient infrastructure, in relation to the surface and population number: a main international airport, a main international sea port, and 10,544 km of roads and 1,156 $\mathrm{km}$ of railways. Although there is sufficient capacity for transport and logistics, the state of the existing infrastructure is the key issue. The transport infrastructure network is sufficiently developed and covers the entire territory of the country, but requires major investments for its renovation and modernization. In some areas where economic growth is projected, the road infrastructure can be extended according to traffic requirements. The road transport sector is relatively competitive in terms of price, despite the general state of bad roads. The sector is dominated by private companies and is considered safe and effective by its 
customers. Following a challenging initial transition, structural reform efforts have been stepped up since 2005 and Moldova's economy has emerged encouraging in the years preceding the crisis. GDP growth accelerated and unemployment declined, although labour force was on a declining trend. Economic growth GDP growth may decelerate further in 2015, with a considerable risk of contraction. Investment has still to recover to pre-crisis levels in Moldova. Therefore, it is estimated that with the exception of some large public investments, investment activity will stagnate over the next few years.

\section{Acknowledgements}

This work is related to the scientific research programme connected with scientific internship of BSc Vadim Postolachi, a student from University of Petrosani in Romania, in the field of education 1041 Traffic and Transportation supported by Erasmus+ programme within Higher Education Learning Agreement for Traineeships between Częstochowa University of Technology in Poland and University of Petrosani in Romania that was conducted since 15.02.2016 to 29.04.2016.

\section{Bibliography}

1. Ralyea J., StePanyan V., Xu T.T., RaZAFimahefa I.F., LiU L.Q., Babici, G. 2015. Romania. Selected Issues. IMF Country Report No. 15/80 International Monetary Fund Washington, D.C.

2. Victor Moroz, Alexandru Stratan, anatolie Ignat, Eugenia Lucasenco. 2015.Country Report: Republic of Moldova. National Institute for Economic Research

3. MOLDOVA Country Strategy 2015-2018. BLACK SEA TRADE AND DEVELOPMENT BANK THESSALONIKI June, 2015.

4. http://www.qreferat.com/referate/transporturi/PORTURILE-MARITIMESI-FLUVIALE253.phpv 
5. http://www.dalserlogistic.md/site/index.php?option=com_content\&view=art icle\&id=24\&Itemid=7\&lang=ro

6. http://www.agerpres.ro/economie/2015/07/10/poim-2014-2020-romania-vaprimi-9-5-miliarde-de-euro-din-partea-ue-pentru-investitii-in-transporturimediu-si-energie-14-20-51

7. http://mt.gov.ro/web14/spatiul-media/comunicate-de-presa/1107-04-032016

8. http://www.wall-street.ro/articol/Companii/193260/antares-anunta-investitiide-7-milioane-euro-pana-in-2019.html

9. http://bnr.ro/files/d/Pubs_ro/InvestitiiStraine/ISD2010.pdf.

10. http://www.bnm.org/ro/content/investitiile-straine-directe-competitivitatearegionala-republicii-moldova

11. http://rtec.md/proiecte/28-proiectul-transport-public.html

12. http://agora.md/stiri/3182/proiect-de-100-milioane-de-euro-caile-ferate-dinmoldova-vor-fi-reparate-pe-bani-europeni

13. http://www.airport.md/news-en/5804/

14. http://www.bbc.co.uk/romanian/news/story/2007/09/070902_moldova_giurg iulesti.shtml

15. http://ceed-romania.org/project-adaptability-to-increase-thecompetitiveness-of-road-transport-in-romania/

16. http://www.statistica.md/newsview.php?l=ro\&idc=168\&id=5047

17. http://www.mec.gov.md/ro/content/portul-international-liber-giurgiulesti

18. http://www.airport.md/passenger-en/ 